\title{
Comparative Analysis of Photosynthetic Activity and PSII Protein Profiles of Some Plants Grown under
}

\section{Enhanced Solar UV-B Radiation}

\author{
Shanthi Natarajan ${ }^{1}$, Savarimuthu Moses Janetta Nithia ${ }^{2}$ and Govindasamy Kulandaivelu ${ }^{3}$ \\ 1. PG and Research Department of Botany, Unit of Plant Stress Physiology, Pachaiyappa's College, Chennai 600032, Tamil Nadu, \\ India \\ 2. Department of Botany, Sri Meenakshi Government Arts College for Women, Madurai 625002, Tamil Nadu, India \\ 3. Centre for Advanced Studies in Botany, University of Madras, Guindy Campus, Chennai 600032, Tamil Nadu, India
}

\begin{abstract}
The deleterious effects of ultraviolet B (UV-B) radiation on photosynthesis and photosynthetic proteins of tropical and temperate plants have been studied. Like tropical plants (black gram and green gram), the temperate plants (carrot and radish) also successfully grown in the tropical region. They were exposed to enhanced UV-B radiation under field condition. Comparative studies show that under enhanced UV-B radiation photosynthetic activity was increased in black gram. In green gram and radish the UV-B radiation slightly enhanced the photosynthetic activity, but it inhibited the photosynthetic activity in carrot. The comparative results showed changes in contents of thylakoid 55, 47, 43, 33, 29, 27-25, 23 and $17 \mathrm{kDa}$ polypeptides that were significantly lowered in UV-B treated carrot plant when compared to other plants. The PSII protein profile results showed a strong correlation between the presence of a membrane polypeptide and photosynthetic activity. In black gram and green gram the UV-B radiation did not produce any significant difference in the PSII polypeptides. As in the case of radish the UV-B radiation increased the accumulation of 33-28 $\mathrm{kDa}$ protein and affected expression of the $63 \mathrm{kDa}$ protein. In the case of carrot, severe degradation of $32 \mathrm{kDa}$ and $33 \mathrm{kDa}$, corresponding to D1 and D2 core proteins of PSII, was observed. It could be concluded that the ability of plants to tolerate increased levels of UV-B radiation, relative to photosynthetic capacity, depends on acclimation processes of the plant in the growing region.
\end{abstract}

Key words: Photosystem II, UV-B radiation, black gram, green gram, carrot, radish.

\section{Introduction}

The ozone layer in the atmosphere has safeguarded life on this planet. It blocks out harmful ultraviolet (UV) rays from the sun. But nowadays emission of ozone depleting substances, such as chloroflurocarbons (CFC) and other man-made chemicals, which react with and reduce the ozone in the stratosphere leading to the continuous increase of the UV radiation at ground level. The most intense of these UV rays, named UV-C $(<280 \mathrm{~nm})$ is completely absorbed by the ozone layer. The radiation in the range of 280-320 $\mathrm{nm}$ (UV-B) is of great interest

Corresponding author: Shanthi Natarajan, Ph.D., research field: plant stress physiology. nowadays, since it includes the shortest wavelengths able to reach earth surface and thus it is the most dangerous for the living beings. The UV radiation in the long wavelength range, UV-A, 320-400 nm, possesses low energy and is quite harmless [1].

The emission of UV-B radiation not uniform throughout the earth surface it varied from low to high latitude. India is one among countries that are close to the equator, thus faces high fluxes of UV radiation with sunlight. The average latitude of India is $20{ }^{\circ} \mathrm{C}$ north of the equator and maximum UV-B (280-320 $\mathrm{nm}$ ) irradiance near the equator (solar elevation angle $<25^{\circ} \mathrm{C}$ ) under clear, sunny skies is approximately 2.5 $\mathrm{Wm}-2$, which may affect the plants function. The plants are unavoidably exposed to UV-B due to the 
need of capturing sunlight for photosynthesis. The UV-B radiation is regarded as a stress factor able to significantly to affect plant growth characteristics, plant height, leaf area and leaf length $[2,3]$. In addition, photosystem II (PSII) function can also be adversely affected by UV-B radiation [4]. Beside the inactivation of PSII, a reduced activity of Rubisco activity, down-regulation of transcription of photosynthetic genes and the decrease in the levels of chlorophyll and carotenoids accumulation have been also observed $[5,6]$.

PSII is pigment-protein complex, which contains reaction core centre is formed by the D1 and D2 proteins [7-9], inner antenna proteins $\mathrm{CP} 47$ and $\mathrm{CP} 43$, the extrinsic protein oxygen evolving complex (OEC) and number of small subunits [10]. The PSII is functionally connected to major light-harvesting complex II (LHCII) and minor antenna proteins CP29, CP26 and CP24, which jointly collect and transfer energy to the reaction centre. The $\mathrm{D} 1$ and $\mathrm{D} 2$ reaction centre proteins are extremely sensitive to UV-B radiation and their degradation may be driven by UV-B radiation. The PSII damage induced by UV-B decreases oxygen evolution or variable chlorophyll fluorescence, whereas minor or no effects have been observed in CP43 and of 17, 23 and $33 \mathrm{kDa}$ extrinsic proteins [11]. The degradation of protein D1 is linked to a dissociation of CP43 subunit, an increase of the accumulation of different low or high molecular proteins or removal of the damaged D1 and its replacement with a newly-synthesized protein [12-14].

The aim of the present study was comparatively analysis of UV-B induced changes in the photosynthetic activity, thylakoid and PSII protein profile of some tropical plants like black gram and green gram and temperate plants like a carrot and radish plants. The black gram and green gram plants are typical tropical species and are grown normally in low latitudes. The tropical region temperature, light and water evaporation is very high when compared to temperate region. The tropical plant system may be vulnerable to a continued increase in UV-B radiation associated with stratospheric ozone depletion. So the tropical plants are thought to have an inherent resistance to UV-B radiation. The temperate plants like carrot and radish successfully grown in the tropical region but encounter much higher levels of UV-B radiation than at higher latitudes. The degree of vulnerability will vary among tropical plant communities. For this experiment, these plants were grown under field conditions and they were exposed to ambient and enhanced UV-B radiation. UV-B enhancement was maintained at $20 \%$ above the ambient level. The thylakoid and PSII protein was isolated from the freshly harvested leaves by standard protocol. The isolated PSII protein was separated by SDS-PAGE electrophoresis.

\section{Materials and Methods}

\subsection{Plant Material and UV-B Treatment}

Certified seeds of Vigna mungo L. (black gram), Vigna radiata L. (green gram), Daucus carota L. (carrot) and Raphanus sativus L. (radish) obtained from the Agriculture Department, Madurai was sown in experimental plots in the Madurai Kamaraj University Botanical Garden. The city of Madurai located at $9.93^{\circ}$ north longitude and $78.12^{\circ}$ east latitude. The city lies at an altitude of 330 feet or 101 $\mathrm{m}$ above sea level. The maximum temperature is $42{ }^{\circ} \mathrm{C}$ and a minimum of $26.3{ }^{\circ} \mathrm{C}$. One set of plants was grown under ambient solar radiation and other under 20\% UV-B enhanced solar radiation supplemented by a Philips TL 40W/12 sunlamp (Gloelampenfabrieken, Holland). The analysis of growth parameters, biochemical constituents and photosynthetic activity, after exposure to enhanced solar UV-B, was carried out at an interval of $5 \mathrm{~d}$. All the parameters were analysed after $10 \mathrm{~d}$ from the onset of UV-B treatment.

\subsection{PSII Electron Transport}

Oxygen evolution $\left(\mathrm{H}_{2} \mathrm{O} \rightarrow\right.$ benzoquinone (BQ)): 
PSII mediated $\mathrm{O}_{2}$ evolution in the presence of BQ as electron acceptor was continuously monitored at $25{ }^{\circ} \mathrm{C}$ in an electrode set up same as described above. The reaction mixture in a total volume of $1.0 \mathrm{~mL}$ contained $50 \mathrm{mM} \mathrm{Na} / \mathrm{K}$ phosphate, $\mathrm{pH} 6.5,5 \mathrm{mM}$ $\mathrm{MgCl}_{2}, 10 \mathrm{mM} \mathrm{NaCl}, 100 \mathrm{mM}$ sucrose, $0.5 \mathrm{mM}$ BQ and chloroplasts equivalent to $20 \mu \mathrm{g}$ chlorophyll (Chl).

\subsection{Isolation of Thylakoid Membran}

Freshly harvested leaf samples were washed in tap water and homogenized in semi frozen isolation buffer containing $50 \mathrm{mM}$ tricine, $\mathrm{pH} 6.9$ and 400 $\mathrm{mM}$ sucrose for 10-20 s at full speed in the Sorvall homogenizer. The homogenate was filtered through eight layers of cheese cloth and the filtrate was spun at $3,000 \mathrm{~g}$ for $5 \mathrm{~min}$ at $4{ }^{\circ} \mathrm{C}$. The pellet was resuspended in a medium containing $100 \mathrm{mM}$ sucrose, $5 \mathrm{mM} \mathrm{MgCl} 2$ and $20 \mathrm{mM}$ Tris, $\mathrm{pH} 7.5$ and centrifuged at $10,000 \mathrm{~g}$ for $5 \mathrm{~min}$ at $4{ }^{\circ} \mathrm{C}$. The resulting pellet represented the thylakoid membranes

\subsection{Isolation of PSII Proteins}

PSII proteins were prepared according to the modified procedure of Kuwabara and Murata [15].

\subsection{PSII Protein Analysed by Electrophoresis Procedures}

PSII protein was analysed by SDS-PAGE on a slab gel of $15 \%$ acrylamide. Samples were solubilised at $20{ }^{\circ} \mathrm{C}$ for $5 \mathrm{~min}$ in $2 \%$ SDS containing $60 \mathrm{mM}$ DTT and $8 \%$ sucrose at an SDS-Chl ratio of 20:1.

\section{Results and Discussion}

\subsection{Changes on Photosynthetic Activity}

The efficiency of photosynthetic activity was determined using an $\mathrm{O}_{2}$ electrode in which the PSII mediated electron transport was assayed individually. The PSII mediated electron transport, measured as $\mathrm{O}_{2}$ evolution, was found to be of the same magnitude in both ambient condition irrespective of the crop (Fig. 1). The rate of $\mathrm{O}_{2}$ evolution was found to increase with the age of the seedlings till $20 \mathrm{~d}$ of treatment and declined thereafter. This trend was noticed in all the four crops grown under ambient and enhanced UV-B condition. In black gram showed higher rate of activity than other plants. Green gram was able to resist the enhanced UV-B. In contrast to these plants, radish showed a marginally increased photosynthetic activity at all the stages of plant growth under UV-B enhanced radiation. In the present investigation UV-B radiation was found to increase the PSII activity in black gram and green gram and such an increase could be due to structural reorganization of the PSII complex which might have resulted in the stabilization of the PSII activity in UV-B enhanced light grown plants. Similar changes in the reorganization of the PSII complex have been reported earlier by Nedunchezhian and Kulandaivelu [16].

Whereas in carrot the enhanced UV-B radiation significantly decreased the PSII activity. The target sites of UV-B in thylakoid membranes were reviewed by Kulandaivelu et al. [17]. Most of the studies reported that PSII as the most vulnerable site for the action of UV-B. Several studies have shown a similar decrease in PSII activity [18]. It was suggested that such changes may be due to the damage caused to the oxidizing side of PSII or to the reaction center itself [19]. Renger et al. [19] have shown UV-B induced damage in the PSII reaction center and correlated this to the functioning of OEC and P680.

The damage to the PSII activity may also be associated with UV-B induced disruption of the structural integrity of the lamellar membrane system in the chloroplast. Such reports were made by Campbell [20] and Brandle et al. [21]. UV induced structural damages to the chloroplasts and to the D1 and D2 proteins of the PSII core complex have also been linked to the decrease in photosynthetic capacity and growth rate [22]. Reduction in PSII activity has also 

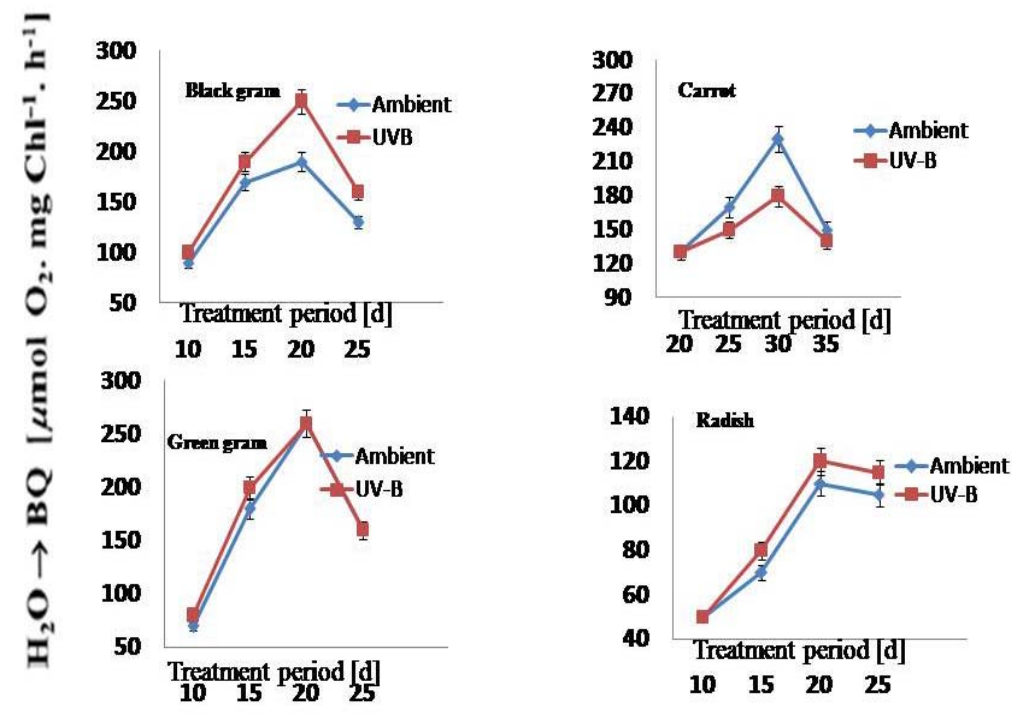

Fig. 1 Changes in the PSII mediated $\left(\mathrm{H}_{2} \mathrm{O} \rightarrow\right.$ benzoquinone (BQ)) electron transport activities in chloroplast isolated from black gram, green gram, radish and carrot plants grown under ambient and enhanced ultraviolet B (UVB) radiation. The values represent an average of five independent measurements and are significant at $\pm 5 \%$ level.

been attributed to the decrease in the number of functional PSII reaction centers [23].

The present study was clear that carrot is a sensitive to UV-B radiation, whereas black gram is highly resistant and green gram and radish are moderately resistant to UV-B radaition. Therefore, further work was extended to analyze the thylakoid polypeptide of the above plants and to correlate the above changes (Fig. 2). In carrot the plants grown under the ambient light condition showed an increase in polypeptides in the range of 18-24 $\mathrm{kDa}$ and 43-55 $\mathrm{kDa}$. UV-B enhanced radiation caused an overall decrease in the level of 55, 47, 33, 27 and $20 \mathrm{kDa}$ polypeptides. UV-B radiation denatures protein and also damages nucleic acids leading to reductions in the amount of stromal and thylakoid proteins. Damages of nucleic acid and thereby the protein synthesis affecting Rubisco, which constitutes about $50 \%$ of the total soluble proteins, by enhanced UV-B radiation have been reported [24, 25]. In many higher plants and macroalgae the Rubisco subunit degradation upon exposure to UV-B have been reported [26, 27]. Suppression of gene expression of key proteins involved in photosynthesis (like $r b c L$ encoding for LSC of Rubisco and psbA for D1) has also been shown $[28,29]$. High UV-B irradiance in combination with low photosynthetic active radiation (PAR) produced significant reduction in the concentration of carboxylating enzyme [30]. High UV-B levels were reported to decrease the amount of carboxylating enzyme and the level of both subunits had decreased [27]. UV-B induced inactivation of Rubisco could be due to the modification of the peptide chain or degradation of the protein and diminished transcription of gene [28, 31].

The loss of $47 \mathrm{kDa}$ polypeptides might be due to the disruption of the PSII complex [32]. The 33, 23 and $17 \mathrm{kDa}$ polypeptide associates are required for optimal functioning of the oxygen evolving machinery. These three polypeptides are present in equimolar amounts [33, 34]. Renger et al. [19] have suggested that the catalytic cluster of water oxidation and especially the $33 \mathrm{kDa}$ polypeptide containing the $\mathrm{Mn}$ cluster is highly sensitive to UV-B radiation. Nedunchezhian and Kulandaivelu [16] reported that UV-B radiation induced destruction of 33, 23 and $17 \mathrm{kDa}$ 


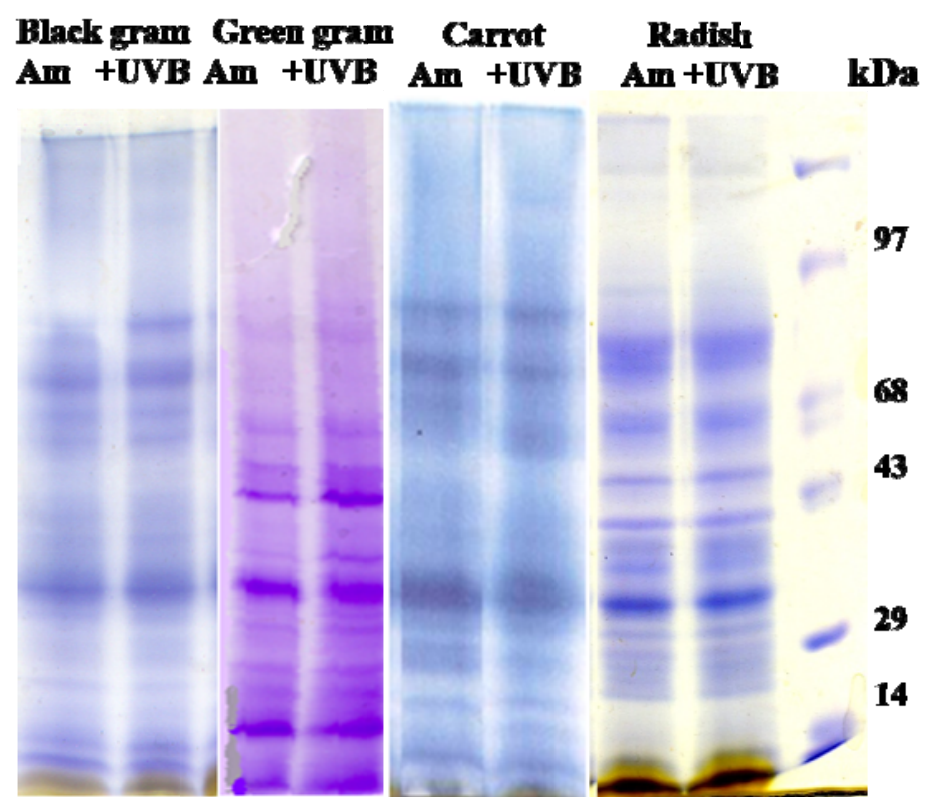

Fig. 2 SDS-PAGE analysis of thylakoid polypeptides isolated from black gram, green gram, radish and carrot plants grown under ambient and enhanced UVB radiation.

Protein sample equivalent to $300 \mu \mathrm{g}$ was loaded in each well. Other details are as under materials and methods. Am: ambient control; +UVB: enhanced UVB.

polypeptides in Vigna chloroplasts. Decrease in the level of these polypeptides or release of any one of these polypeptides from the thylakoid could result in low efficiency of the $\mathrm{O}_{2}$ evolving apparatus. As in the case of black gram, green gram and radish did not show much change in the composition and quantity of the thylakoid polypeptides.

PSII is multisubunit membrane protein complexes that catalyse the light induced splitting of water there by sustaining aerobic life on the planet. The PSII is a large pigment protein complex found in thylakoid membrane of plants. The core complex made up of six major extrinsic protein D1, D2, CP47, CP43, $\alpha, \beta$ subunits. For oxygen evolution, plants require an additional set of four lumen-exposed extrinsic protein with apparent molecular masses of 33, 23, 17 and 10 $\mathrm{kDa}$ which form the so called oxygen evolution complex. The primary target site of the UV-B radiation has been identified as a PSII [19, 35], which could reveal photoinactivation, photodamage of PSII by UV-B [36]. The photodamage not only impairs the electron transport of PSII, but also destroys in protein structure.

\subsection{Changes on PSII Protein Profile}

The further studies to found that specific change in the polypeptide associated with the PSII core complex of the UV-B treated and ambient grown plants like black gram, green gram, carrot and radish. The PSII was isolated from the above plant, it was solubilised and polypeptide composition was analyzed in SDS-PAGE electrophoresis. The PSII polypeptide compositions of ambient and enhanced UV-B treated plants were different in all these plants.

The major effect of UV-B on PSII proteins was a breakdown of the reaction centre of the $\mathrm{D} 1$ protein. This was observed in UV-B treated carrot and radish. The degradation of D1 protein was high in carrot plant compare to radish. The UV-B induced loss of D1 protein has been shown in Fig. 3. The D1 and D2 proteins degrade rapidly when the plants are UV-B irradiated. The PSII reaction centre stability may be limited by sensitization of UV-B driven D1 protein degradation [37]. The increased degradation of protein D1 under UV-B radiation may be explained as the consequence of two independent mechanisms. The first 


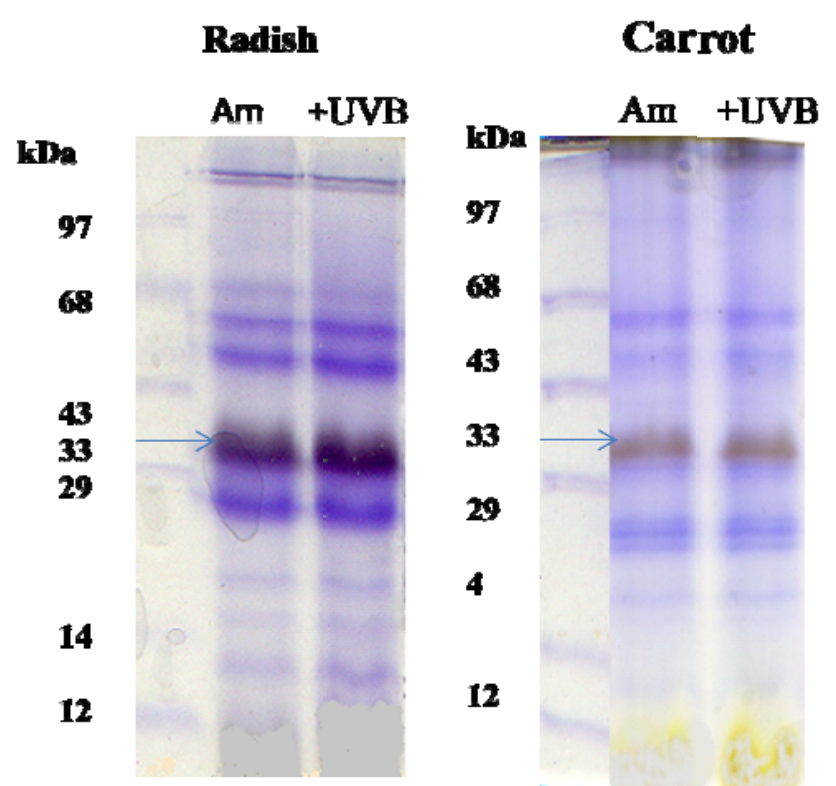

Fig. 3 SDS-PAGE analysis of PSII polypeptides isolated radish and carrot plants grown under ambient and enhanced UVB radiation.

Protein sample equivalent to $25 \mu \mathrm{g}$ was loaded in each well. Other details are as under materials and methods.

Am: ambient control; +UVB: enhanced UVB.

includes the direct damage to the donor side of PSII through impairment of manganese cluster [19] or the donor site components [36] which lead to cleavage of the protein in the second transmembrane helix [12]. The second mechanism may be ascribed to induced dephosphorylation of PSII, which favors the turnover of D1 protein [37]. Recently, Kataria et al. [38] revealed the UV-B damage sites it includes OEC on the donor sides of the PSII, D1 and D2 reaction centre proteins.

The UV-B radiation not only degraded D1 protein, it also damaged other thylakoid subunits such as CP43, CP47 and OEC. However, the loss of protein accompanied by the appearance of the specific degradation product like $23 \mathrm{kDa}$ and $63 \mathrm{kDa}$ proteins was found in radish plant. In the case of carrot, a number of fragments were detected with apparent mass between 29-20 $\mathrm{kDa}$. However, in carrot, the UV-B exposure decreased the low molecular weight proteins of 20, 18 and $14 \mathrm{kDa}$ in comparison with radish. Studies carried out using in vitro system have shown that irradiation with UV lead to the loss of D1 protein accompanied by the appearance of an immune detectable fragment of $20 \mathrm{kDa}$ [39]. Moreover, some plants respond to enhanced UV-B irradiance by elevating their UV-B screening capacity [2, 40-42] thereby protecting PSII activity and PSII complex can be repaired. This process is the first example of simultaneous D1 and D2 protein repair in PSII and considered to function as an important defence mechanism against detrimental UV-B effects in oxygenic photosynthetic organisms. De novo synthesis of the D1 and D2 reaction centre subunits is a key step of the repair process by which damaged protein replaced by newly synthesised PSII protein [43, 44]. Similar result was observed in black gram and green gram and accumulation of D1/33 $\mathrm{kDa}$ protein was noticed in both the plants (Fig. 4). In black gram and green gram the oxygen evolving complex was highly stable and there no decrease in the level of intrinsic proteins was observed under UV-B treatments. However, as UV-B increases in the environment, this threshold may be more often reached, especially in UV-B susceptible species. Indeed, Booij et al. [45] using UV-B-sensitive (cv. CNS) and tolerant (cv. Williams) soybean cultivars, have found that under PAR the kinetics of D1 and D2 degradation were similar for the two cultivars. However, 


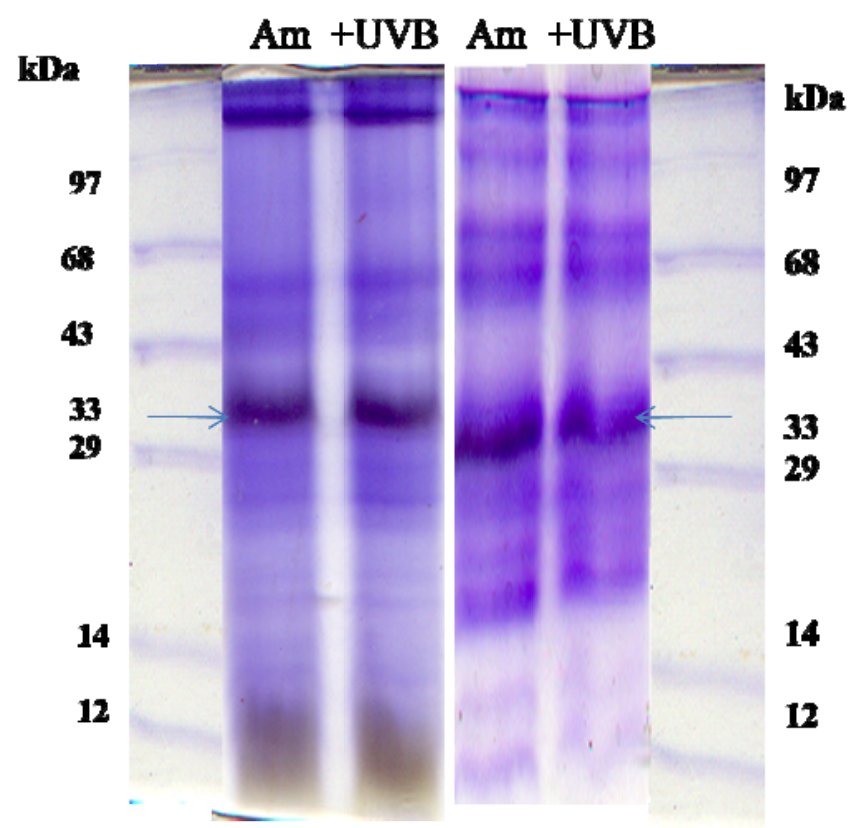

Fig. 4 SDS-PAGE analysis of PSII polypeptides isolated from black gram and green gram, plants grown under ambient and enhanced UVB radiation.

Protein sample equivalent to $25 \mu \mathrm{g}$ was loaded in each well. Other details are as under materials and methods. Am: ambient control; +UVB: enhanced UVB.

under UV-B radiation and particularly in UV-B plus PAR, the degradation of the D1-D2 heterodimer was significantly enhanced in cv. CNS when compared with cv. Williams. In green gram plant the UV-B radiation increase the accumulation of 68,70 and 97 $\mathrm{kDa}$ protein. Rajagopla et al. [13] clearly demonstrated PSII core antenna of chlorophyll proteins $\mathrm{CP} 47$ and $\mathrm{CP} 43$ are affected by UV-B exposure. Further the prominent $94 \mathrm{kDa}$ protein band appears in green gram it not induced by UV-B radiation but could possibly cross linking of thylakoid. Similar cross-linked products of the D1 protein were also observed in cyanobacterial thylakoids exposed to high light intensity [46]. Thus, it is likely that cross-linking of the D1 protein with neighboring proteins is a general occurrence in oxygenic photosynthetic organisms subjected to excessive light. To maintain PSII activity, the oxidatively damaged D1 protein is replaced by a newly synthesized protein [47].

\section{Conclusions}

This study concludes that the degree of UV-B mediated changes of photosynthetic activity, thylakoid and PSII protein damage and repair cycle depends on plant natural habitat. Because the effect of natural solar UV-B radiation depends on the acclimation of plant in the growing region. However, exposing plants to enhance UV-B radiation may accelerate the UV-B effect on D1 degradation and this effect was higher in the temperate plants like carrot and radish, than in the tropical plants. The rate of net D1 damage was faster in temperate plants in the tropical communities, likely due to the effects of high natural solar light, temperature and quick evaporation of water on the mechanism of protein degradation and synthesis. But the degree of vulnerability will vary among tropical plant communities. The tropical plants are capable of effectively protecting their leaves against UV-B stress and stabilizing the D1 protein damage and restore the PSII activity.

\section{References}

[1] Stapleton, A. E. 1992. "Ultraviolet Radiation and Plants: Burning Questions.” Plant Cell 4 (11): 1353-8. 

Some Plants Grown under Enhanced Solar UV-B Radiation

[2] Teramura, A. H., and Sullivan, J. H. 1994. "Effects of UV-B Radiation on Photosynthesis and Growth of Terrestrial Plants.” Photosynth. Res. 39 (3): 463-73.

[3] Rozema, J., van de Staaij, J., Björn, L. O., and Caldwell, M. 1997. "UV-B as an Environmental Factor in Plant Life: Stress and Regulation.” Trends Ecol. Evol. 12 (1): 22-8.

[4] Tevini, M., Braun, J., and Fieser, G. 1991. "The Protective Function of the Epidermal Layer of Rye Seedlings against Ultraviolet-B Radiation." Photochem. Photobiol. 53: 329-33.

[5] Greenberg, B. M., Wilson, M. I., Huang, X. D., Duxbury, C. L., Garhardt, K. E., and Gensemer, R. W. 1997. "The Effects of Ultraviolet-B Radiation on Higher Plants." In Plants for Environmental Studies, edited by Wang, W., Gorsuch, J. W., and Hughes, J. S. Boca Raton, Florida: CRC Press, 1-36.

[6] Jansen, M. K., Gaba, V., and Greenberg, B. M. 1998. "Higher Plant and UV-B Radiation: Balancing Damage, Repair and Acclimation." Trends in Plant Sciences 3: 131-5.

[7] Mattoo, A. K., Marder, J., and Edelman, M. 1989. "Dynamics of the Photosystem II Reaction Center." Cell 56 (2): 241-6.

[8] Mattoo, A. K., Giardi, M. T., Raskind, A., and Edelman, M. 1999. "Dynamic Metabolism of Photosystem II Reaction Center Proteins and Pigments." Physiol. Plant 107: 454-61.

[9] Takahashi, K., Takabayashi, A., Tanaka, A., and Tanaka, R. 2014. "Functional Analysis of Light-Harvesting-Like Protein 3 (LIL3) and Its Light-Harvesting Chlorophyll-Binding Motif in Arabidopsis." J. Biol. Chem. 289 (2): 987-99.

[10] Baena-González, E., and Aro, E. M. 2002. "Biogenesis, Assembly and Turnover of Photosystem II Units." Philosophical Transactions of the Royal Society B: Biological Sciences 357 (1426): 1451-60.

[11] Ithle, C. 1997. "Degradation and Release from the Thylakoid Membrane of Photosystem II Subunits after UV-B Irradiation of the Liverwort Conocephalum conicum." Photosynth. Res. 54: 73-8.

[12] Friso, G., Barbato, R., Giacometti, G. M., and Barber, J. 1994. "Degradation of D2 Protein Due to UV-B Irradiation of the Reaction Centre of Photosystem." FEBS Lett. 339 (3): 217-21.

[13] Rajagopala, S., Murthya, S. D. S., and Mohantyc, P. 2000. "Effect of Ultraviolet-B Radiation on Intact Cells of the Cyanobacterium Spirulina platensis: Characterization of the Alterations in the Thylakoid Membranes." Journal of Photochemistry and Photobiology 54 (1): 61-6.

[14] Jarvi, S., Suorsa, M., and Aro, E. M. 2015. "Photosystem II Repair in Plant Chloroplasts-Regulation, Assisting
Proteins and Shared Components with Photosystem II Biogenesis.” Biochim. Biophys. Acta. 1847 (9): 900-9.

[15] Kuwabara, T., and Murata, N. 1982. "Inactivation of Photosynthetic Oxygen Evolution and Concomitant Release of Three Polypeptides in the Photosystem II Particles of Spinach Chloroplasts." Plant Cell Physiol. 23: 533-9.

[16] Nedunchezhian, N., and Kulandaivelu, G. 1991. "Effects of UV-B Enhanced Radiation on Ribulose 1,5-bisphophate Carboxylase in Leaves of Vigna sinensis L." Photosynthetica 25: 431-5.

[17] Kulandaivelu, G., Lingakumar, K., and Premkumar, A. 1997. "UV-B Radiation." In Plant Ecophysiology, edited by Prasad, M. N. V. U.S.A.: John Wiley \& Sons, 41-59.

[18] Van Hasslet, P. R. 1974. "Photo-Oxidation of Unsaturated Lipids in Cucumber Leaf Discs during Chilling." Acta Botanica Neerlandica 23 (2): 159-69.

[19] Renger, G., Völker, M., Eckert, H. J., Fromme, R., Hohm-Veit, S., and Gräber, P. 1989. "On the Mechanism of Photosystem II Deterioration by UV-B Irradiation." Photochem. Photobiol. 49 (1): 97-105.

[20] Campbell, W. S. 1975. "Ultraviolet Induced Ultrastructural Changes in Mesophyll Cells of Glycine Max." In Impacts of Climatic Changes on the Biosphere, Part I. Ultraviolet Radiation Effects, edited by Nachtwey, D. S., Caldwell, M. M., and Biggs, R. H. Monogr. 5 Climatic Impact Assessment Program, US Dept. Transportation Rep No. DOT-IST-75-55. Nat. Tech. Info. Serv., Springfield, VA, 167-76.

[21] Brandle, J. R., Campbell, W. F., Sisson, W. B., and Caldwell, M. M. 1977. "Net Photosynthesis, Electron Transport Capacity and Ultrastructure of Pisum sativum L. Exposed to UV-B Radiation.” Plant Physiol. 60: 165-9.

[22] Teramura, A. H., and Ziska, L. H. 1996. "Ultraviolet-B Radiation and Photosynthesis." In Photosynthesis and the Environment, edited by Baker, N. R. Netherlands: Kluwer Acad. Publ., 435-50.

[23] Chow, W. S., Hope, A. B., and Anderson, J. M. 1991. "Further Studies on Quantifying Photosystem II in Vivo by Flash-Induced Oxygen Yield from Leaf Discs." Aust. J. Plant Physiol. 18: 397-410.

[24] Vu, C. V., Allen, L. H., and Garrard, L. H. 1984. "Effects of Enhanced UV-B Radiation (280-320 nm) on Ribulose-1,5-bisphosphate Carboxylase in Pea and Soybean." Env. Exp. Bo. 24 (2): 131-43.

[25] Strid, A., Chow, W. S., and Anderson, J. M. 1990. "Effects of Supplementary Ultraviolet-B Radiation on Photosynthesis in Pisum sativum." Biochem. Biophys. Acta 1020 (3): 260-8.

[26] Greenberg, B. M., Wilson, M. I., Gerhardt, K. E., and Wilson, K. E. 1996. "Morphological and Physiological Responses of Brassica napus to Ultraviolet-B Radiation: 

Some Plants Grown under Enhanced Solar UV-B Radiation

Photomodification of Ribulose-1,5-bisphosphate Carboxylase/Oxygenase and Potential Acclimation Processes." Journal of Plant Physiology 148 (1-2): 78-85.

[27] Bischof, K., Hanlet, D., and Wiencke, C. 2000. "Effects of Ultraviolet Radiation on Photosynthesis and Related Enzyme Reactions of Marine Macroalgae.” Planta 211 (4): 555-62.

[28] Jordan, B. R., He, J., Chow, W. S., and Anderson, J. M. 1992. "Changes in mRNA Levels and Polypeptide Subunits of Ribulose-1,5-bisphosphate Carboxylase in Response to Supplemental UV-B Radiation.” Plant Cell Environ. 15 (1): 91-8.

[29] Mackerness, S. A. H., Jordan, B. R., and Thomas, B. 1999. "Reactive Oxygen Species in the Regulation of Photosynthetic Genes by Ultraviolet-B Radiation (UV-B: 280-320 nm) in Green and Etiolated Buds of Pea (Pisum sativum L.)." J. Photochem. Photobiol. B: Biol. 48 (2-3): 180-8.

[30] Barbato, R., Frizzo, A., Frizzo, G., Rigoni, F., and Giacometti, G. M. 1995. "Degradation of the D1 Protein of Photosystem II Reaction Centre by Ultraviolet-B Radiation Requires the Presence of Functional Manganese on the Donor Side." Eur. J. Biochem. 227 (3): 723-9.

[31] Jordan, B. R., James, P. E., Strid, A., and Anthony, R. G. 1994. "The Effect of UV-B Radiation on Gene Expression and Pigment Composition in Etiolated and Green Pea Leaf Tissue: UV-B Induced Changes in Gene Expression Are Gene Specific and Dependent upon Tissue Development." Plant Cell Environ. 17: 45-54.

[32] Caldwell, C. R. 1993. "Ultraviolet-Induced Photodegradation of Cucumber (Cucumis sativus L.) Microsomal and Soluble Protein Tryptophanyl Residues in Vitro." Plant Physiol. 101 (3): 947-53.

[33] Iwanzik, W., Tevini, M., Dohnt, G., Voss, M., Weiss, W., Grāber, P., and Renger, G. 1983. "Action of UV-B Radiation on Photosynthetic Primary Reaction in Spinach Chloroplast." Physiol. Plant. 58 (3): 401-7.

[34] Seidler, A. 1994. "Expression of the $23 \mathrm{kDa}$ Protein from the Oxygen-Evolving Complex of Higher Plants in Escherichia coli." Biochim. Biophys. Acta 1187 (1): 52-8.

[35] Larkum, A. W. D., Karge, M., Reifarth, F., Eckert, H. J., Post, A., and Renger, G. 2001. "Effect of Monochromatic UV-B Radiation on Electron Transfer Reactions of Photosystem II." Photosynth. Res. 68: 49-60.

[36] Vass, I., Sass, L., Spetea, C., Bakou, A., Ghanotakis, D. F., and Petrouleas, V. 1996. "UV-B-Induced Inhibition of Photosystem II Electron Transport Studied by EPR and Chlorophyll Fluorescence. Impairment of Donor and Acceptor Side Components." Biochemistry 35 (27):
8964-73.

[37] Jansen, M. A. K., Greenberg, B. M., Edelman, M., Mattoo, A. K., and Gaba, V. 1996. "Accelerated Degradation of the D2 Protein of Photosystem II under Ultraviolet Radiation." Photochem. Photobiol. 63: 814-7.

[38] Kataria, S., Jain, A., and Guruprasad, K. N. 2014. "Impact of Increasing Ultraviolet-B (UV-B) Radiation on Photosynthetic Processes." Journal of Photochemistry and Photobiology B: Biology 137: 55-66.

[39] Rintamäki, E., Kettunen, R., and Aro, E. M. 1996. "Differential D1 Dephosphorylation in Functional and Photodamaged Photosystem II Centers: Dephosphorylation Is a Prerequisite for Degradation of Damaged D1." J. Biol. Chem. 271 (25): 14870-5.

[40] Friso, G., Vass, I., Spetea, C., Barber, J., and Barbato, R. 1995. "UV-B Induced Degradation of the Dl Protein in Isolated Reaction Centres of Photosystem II." Biochimica and Biophysics Acta 1231 (1): 41-6.

[41] Reddy, V. S., Goud, K. V., Sharme, R., and Reddy, A. R. 1994. "Ultraviolet-B-Responsive Anthocyanin Production in a Rice Cultivar Is Associated with a Specific Phase of Phenylalanine Ammonia Lyase Biosynthesis." Plant Physiol. 105: 1059-66.

[42] Robberecht, R., and Caldwell, M. M. 1983. "Protective Mechanisms and Acclimation to Solar Ultraviolet-B Radiation in Oenothera stricta." Plant Cell Environ. 6 (6): 477-85.

[43] Wellmann, E. 1976. "Specific Ultraviolet Effects in Plant Morphogenesis." Photochem. Photobiol. 24 (6): 659-60.

[44] Wilson, M. I., and Greenberg, B. M .1993. "Specificity and Photomorphogenic Nature of Ultraviolet-B Induced Cotyledon Curling in Brassica napus L." Plant Physiol. 102: 671-7.

[45] Booij-James, I. S., Dube, S. K., Jansen, M. A., Edelman, M., and Mattoo, A. K. 2000. "Ultraviolet-B Radiation Impacts Light-Mediated Turnover of the Photosystem II Reaction Center Heterodimer in Arabidopsis Mutants Altered in Phenolic Metabolism." Plant Physiology 124: 1275-83.

[46] Nixon, P. J., Michoux, F., Yu, J., Boehm, M., and Komenda, J. 2010. "Recent Advances in Understanding the Assembly and Repair of Photosystem II." Ann. Bot. 106 (1): 1-16.

[47] Lupinkova, L., and Komenda, J. 2004. "Oxidative Modifications of the Photosystem II D1 Protein by Reactive Oxygen Species: From Isolated Protein to Cyanobacterial Cells." Photochem. Photobiol. 79 (2): 152-62. 